Canadian Studies in Population, Vol. 32.2, 2005, pp. 229-255

\title{
Evaluation of Projections of Populations for the Aboriginal Identity Groups in Canada, 1996-2001
}

\author{
Ravi B. P. Verma \\ Statistics Canada \\ Ottawa, Ontario, Canada
}

\begin{abstract}
The population projections for the Aboriginal identity groups (North American Indians, Métis and Inuit) by age and sex from 1996 to 2001 were developed at the Canada level, using the cohort-component method. The purpose of this paper is to compare and analyze the error of closure between the projected 2001 and adjusted 2001 population counts due to net census undercounts. It is observed that the error of closure for the 2001 projected Aboriginal population based on the 1996 adjusted census population seems to be lower by $7 \%$ over the 2001 Census adjusted Aboriginal population. In contrast, the projected populations for North American Indians and Inuit are lower by $-0.20 \%$ and $-2.73 \%$. However, for the Métis the error of closure is extremely high, at $-24.84 \%$. Reasons for the higher error of closure for the Métis such as the effects of intra-generational ethnic mobility will be discussed in the paper.
\end{abstract}

Key Words: Population projections, aboriginal population, fertility, mortality, ethnic mobility 
Ravi B. P. Verma

\section{Résumé}

Les projections de la population furent développées au niveau du Canada selon la méthode des composantes des cohortes pour les groupes d'identité autochtone (Indiens de l'Amérique du Nord, Métis, Inuit) selon l'âge et le sexe de 1996 à 2001. L'objet de cet article est de comparer et d'analyser l'erreur en fin de période dû au sous-dénombrement net du recensement entre les chiffres projetés de la population de 2001 et les chiffres rajustés de 2001. L'erreur en fin de période de la population autochtone projetée de 2001 d'après la population du Recensement de 1996 semble être moindre de 7\% que la population autochtone rajustée du Recensement de 2001. En revanche, les populations projetées des Indiens de l'Amérique du Nord et des Inuits sont moindres de $-0,20 \%$ et de $2,73 \%$. Par contre, l'erreur en fin de période est extrêmement élevée pour les Métis à $-24,84 \%$. Les raisons de cette erreur en fin de période plus élevée chez les Métis telles que les effets de la mobilité ethnique intragénérationelle seront discuter dans cette article.

Mots clés: Projections de la population, population autochtone, fécondité, mortalité, mobilité ethnique

\section{Introduction}

The population projections for the three Aboriginal identity groups (North American Indians, Métis and Inuit) were developed at the Canada level, using the cohort-component method. The projections were produced by age and sex annually from 1996 to 2001 . The purpose of these projections was to compare the error of closure between the projected 2001 and adjusted 2001 population counts at the Canada level. The error of closure would provide an expected level of the difference between the observed and the projected population for the fifth year. Before presenting the results of the comparison between the projected and observed 2001 population, the details of the base population, and components of population change involved in developing these projections are presented below. 
Evaluation of Population Projections for the

Aboriginal Identity Groups in Canada: 1996-2001

\section{Base Population}

The base population is the 1996 census counts, adjusted due to net census undercounts and multiple responses for the Aboriginal identity groups by single year of age $(0,1,2 \ldots 85+)$ and sex. At the Canada level, the adjusted 1996 census counts for the total and three Aboriginal identity groups were: 904,252 for the total, 647,993 for the North American Indians, 214,207 for the Métis and 42,051 for the Inuit.

\section{Components of Population Change}

Population projections were developed using the fertility, mortality and ethnic mobility assumptions.

\section{Fertility Projection Method}

A parametric model, namely, the Pearson Type I curve was applied to project the total number of births for the component approach. In this model, the projected age-specific fertility rates are derived from three parameters, the total fertility rate, the mean age of fertility, and the modal age of fertility. The total number of births is obtained by multiplying the model-based age- specific fertility rates with the mid-year projected number of female population aged 1549 for the years $t$ and $t+1$. The distribution of births by sex is calculated according to an assumed sex ratio at birth of 105 males per 100 females.

Total fertility rate: Total fertility rates (TFRs) for each of the three identity groups for the year 1996 were taken from the work done by Ram (2003). He computed the TFRs for the total Aboriginal group and three Aboriginal identity groups using the Own-Children procedure and the 1996 census data on the number of children in the age group 0-4 and the female population by the five year age groups 15-49. For the year 2001, the total fertility rates were also developed using the Own-Children procedure and the 2001 census data on the number of children in the age group 0-4 and the female population by the five year age groups 15-49. For the individual years between 1996 and 2001, the TFRs shown in Table 1 for the total and each of the Aboriginal identity groups were linearly interpolated to decline at the 2001 levels of TFRs. For example, the total fertility rate for the total Aboriginal group declined from 2.7 children in 1996 to 2.5 children per woman in 2001. For the North American Indians and Métis groups, the levels of the decline in the TFRs were lower than that for the Inuit group. For the latter group, the TFR declined considerably from 3.5 children in 1996 to 2.9 children per woman in 2001. 
Ravi B. P. Verma

Table 1

Linear Estimation of TFR per Annum for Aboriginal Groups, 1996-2001

\begin{tabular}{lcccc}
\hline Year & $\begin{array}{c}\text { Total } \\
\text { Aboriginal } \\
\text { Groups }\end{array}$ & NAI & Métis & Inuit \\
\hline $1996-1997$ & 2.70 & 2.88 & 2.28 & 3.52 \\
$1997-1998$ & 2.65 & 2.84 & 2.22 & 3.37 \\
$1998-1999$ & 2.60 & 2.81 & 2.15 & 3.21 \\
$1999-2000$ & 2.55 & 2.78 & 2.08 & 3.05 \\
$2000-2001$ & 2.50 & 2.74 & 2.02 & 2.90 \\
\hline
\end{tabular}

\section{Mean and Modal Ages}

Mean and modal ages of fertility were computed from the age-specific fertility rates based on the Own-Children procedure derived from the 1996 and 2001 Censuses. These mean and model ages were interpolated for the intermediate years, 1996 to 2001. Table 2 shows the mean and modal ages of fertility for the total Aboriginal group and the three identity groups. It is observed that for the Inuit group, both mean and modal ages of fertility are considerably higher than those for the North American Indians and Métis groups.

For the Inuit group, it is seen that as compared to other Aboriginal groups, both TFRs and mean ages of fertility are high. One could think that the Inuit should have lower mean ages, as their fertility rate is higher over other identity groups. In order to clarify this, we have examined the historical relationship between the TFRs and Mean ages of fertility for the total Canadian population from 1921 to 2000. In Appendix Table 1 it can be seen that mean age was high at the early years when TFR was high. It started to decline in the last two decades when TFR starts to decline to low level. The mean age of fertility for the Inuit is higher than the other Aboriginal groups may be due to their persistent high TFR, while the TFRs of other Aboriginal groups have started to decline. 
Evaluation of Population Projections for the Aboriginal Identity Groups in Canada: 1996-2001

Table 2

Mean and Modal Ages of Fertility for Aboriginal Identity Groups, Canada, 1996 to 2001

\begin{tabular}{lcccc}
\hline Year & $\begin{array}{c}\text { Total } \\
\text { Aboriginal } \\
\text { Groups }\end{array}$ & NAl & Métis & Inuit \\
\hline $\begin{array}{c}\text { Mean Ages } \\
1996\end{array}$ & 25.6 & 25.6 & 25.3 & 28.0 \\
1997 & 25.6 & 25.6 & 25.5 & 27.8 \\
1998 & 25.7 & 25.6 & 25.6 & 27.6 \\
1999 & 25.7 & 25.6 & 25.7 & 27.4 \\
2000 & 25.7 & 25.6 & 25.7 & 27.4 \\
2001 & 25.7 & 25.6 & 25.7 & 27.4 \\
& & & & \\
Modal Ages & & & & \\
1996 & 21.3 & 21.3 & 21.7 & 23.2 \\
1997 & 21.3 & 21.2 & 21.8 & 23.0 \\
1998 & 21.3 & 21.1 & 21.9 & 22.9 \\
1999 & 21.4 & 21.1 & 22.1 & 22.7 \\
2000 & 21.4 & 21.1 & 22.1 & 22.7 \\
2001 & 21.4 & 21.1 & 22.1 & 22.7 \\
\hline
\end{tabular}

\section{Mortality Projection Method}

Projecting the Aboriginal population by identity groups requires the estimation of life expectancy at birth and life tables to provide survival ratios by sex and single year of age from birth onward. First, the life expectancy at birth was estimated for each Aboriginal identity group for the two years, 1996 and 2001. The life expectancy at birth for the Registered Indians was computed based on the adjusted number of deaths and population due to their late and never reporting in the Indian Registry Data file. For the non-status Indians and Métis groups, life expectancy at birth was based on the average of life expectancy at birth for the Registered Indians and the life expectancy at birth for the $5^{\text {th }}$ quintile of the general population. The life expectancy at birth for the fifth quintiles (Q5) based on the vital statistics and Census data were developed by Finès (2004) for the year, 1996. For the Inuit group, the life expectancy at birth was based on the average of the life expectancy at birth derived from the vital statistics and population estimates for Nunavut territory and the life expectancy 
Ravi B. P. Verma

at birth cited in the Quebec study by Létourneau, E. (1994), Projections de la population des Inuit du Québec, 1991-2016 in Statistiques sociodémographiques, Bureau de la statistique du Québec. Table 3 presents the estimated life expectancy at birth by the Aboriginal identity groups at the Canada level for the two years 1996 and 2001.

Based on the values of the life expectancy at birth by the Aboriginal identity groups, the life tables were selected from the Canadian historical life tables. Then, the Lx columns were used to compute the survival ratios by age and sex for both years, 1996 and 2001. For the intermediate years, 1997, 1998...2000, the survival ratios were linearly interpolated.

Table 3

Estimated Life Expectancy at Birth by Sex, Status Indian, Non-Status Indian, Métis and Inuit, Canada, 1996 and 2001

\begin{tabular}{lcrrrr}
\hline & & \multicolumn{2}{c}{1996} & \multicolumn{2}{c}{2001} \\
\cline { 3 - 6 } Aboriginal Identity Groups & Methods & Male & Female & Male & Female \\
\hline Total Aboriginal & A & 67.3 & 74.4 & 69.1 & 75.6 \\
North American Indians & B & 69.3 & 75.7 & 71.4 & 76.8 \\
Status Indian & C & 68.1 & 74.3 & 70.4 & 75.4 \\
Non-status Indian & D & 70.5 & 77.0 & 72.4 & 78.2 \\
Métis & E & 70.5 & 77.0 & 72.4 & 78.2 \\
Inuit & F & 62.1 & 70.6 & 63.5 & 71.7 \\
Fifth Quintile (Q5) & G & 72.95 & 79.82 & 74.50 & 80.98 \\
Total Canadians & H & 75.4 & 81.0 & 77.0 & 82.2 \\
\hline
\end{tabular}

Note on methods:
A Average of expectation of life for status, Non-Status, Métis and Inuit
B Average of Expectance of life for Status and Non-status Indians
C Second update of population projections for Regd Indians, 2002 2001: Based on Life Table for 2000 prepared by survival ratio
D Average of expectation of life at birth for Regd Indians and Fifth Quintile
$\boldsymbol{E}$ Average of expectation of life at birth for Regd Indians and Fifth Quintile
$\boldsymbol{F}$ For Canada, an average of East \& West was used. 1996 Inuit Female was derived by using the average of the Quebec data dans Nunavut data. The Nunavut data comes from: Statistics Canada and $\mathrm{ClHI}$, Health Indicators, June 2001, Catalogue no. 82-221-XIE
G Life Expectancy at birth by Finés (2004) for the fifth Qintiles (Q5)
H Official Life Tables and Report on the Demographic Situation in Canada, 2002 
Evaluation of Population Projections for the Aboriginal Identity Groups in Canada: 1996-2001

\section{Ethnic Mobility}

Intergenerational ethnic mobility refers to the ethnic identity of a child different from that of his /her parents. In the projections, this mobility in ethnic identity is assumed to happen at birth, thus the assumption on ethnic mobility has a direct impact on births. So, the intergenerational ethnic mobility, measured by the continuity index based on children aged 0-4 by Aboriginal groups from the 1996 and 2001 censuses, was incorporated by inflating the number of births to include those births that have a different ethnic identification from their mothers. The continuity index is defined as the total number of children with a given identity divided by the total number of children born to mothers with the same identity. Table 4 shows the continuity indices by Aboriginal identity groups for the Canada level from the 1996 and 2001 censuses. Between 1996 and 2001, there are some differences in the continuity indices for the North American Indians and Métis groups. However, in the projections the level of continuity index based on the 1996 census for each Aboriginal identity group was kept constant for the projection years, 1996 to 2001.

Table 4

Continuity Index based on Children aged 0-4, by Aboriginal Groups for Canada, 1996 and 2001 Censuses

\begin{tabular}{lcc}
\hline Aboriginal Identity groups & $\mathbf{1 9 9 6}$ & $\mathbf{2 0 0 1}$ \\
\hline North American Indians & 105.9 & 109.2 \\
Métis & 116.5 & 114.5 \\
Inuit & 103.6 & 103.1 \\
\hline
\end{tabular}

Two sets of population projections were developed. The first set of the population projections by Aboriginal identity groups was based on fertility and mortality assumptions. The second set of the population projections was based on fertility, mortality and ethnic mobility. In both sets of projections, the international migration among the Aboriginal Identity groups was assumed to be zero. 


\section{Analysis of Results}

In this section, the differences between the projected 2001 population and the adjusted 2001 population counts due to the net census undercounts and multiple responses are analyzed by Aboriginal identity group controlling for sex at the Canada level.

Table 5 shows the error of closure between the projected 2001 Aboriginal population by identity groups without ethnicity and the 2001 adjusted census counts. Table 6 shows the effect of ethnicity on the error of closure between them.

In Table 5, the comparison of the projected population in 2001-based on the 1996-based Aboriginal population with the adjusted 2001 census counts shows the following major findings:

- As compared to the 2001 census adjusted Aboriginal population, the error of closure for the 2001 projected Aboriginal pop based on the 1996 adjusted census population seems to be lower by $7.4 \%$.

- The errors of closure for the North American Indians and Inuit are relatively much lower, $-0.20 \%$ and $-2.73 \%$. However, for the Métis group the error of closure is extremely high, at $-24.84 \%$.

- $\quad$ The reasons for the higher error of closure for the Métis could be due to ethnic mobility and also, due to weakness with the methodology for estimating expectation of life at birth.

In Table 6, the 2001 projected population including the intergenerational ethnic mobility based on the 1996-based continuity index was evaluated with the adjusted 2001 census counts. It is seen that with ethnicity there has been a slight reduction in the error of closure for the Métis population, $-23.77 \%$ and $24.84 \%$. For the Inuit, the error of closure has also been reduced, $-2.34 \%$ and $2.73 \%$. However for the North American Indians the error of closure has increased positively, $0.43 \%$ and $-0.20 \%$. 
Evaluation of Population Projections for the Aboriginal Identity Groups in Canada: 1996-2001

Table 5

Evaluation of 1996 based Projections of Aboriginal Population (without Ethnic Mobility Assumption) with the 2001 Adjusted Census Counts, Canada

\begin{tabular}{|c|c|c|c|c|c|}
\hline & $\begin{array}{r}1996 \text { Adj. Census } \\
\text { Population Counts } \\
\text { (A) }\end{array}$ & $\begin{array}{r}\text { Projected } 2001 \\
\text { Population } \\
\text { (B) }\end{array}$ & $\begin{array}{r}2001 \text { Adj. Census } \\
\text { Population Counts } \\
\text { (C) }\end{array}$ & $\begin{array}{c}\text { Difference } \\
D=B-C \\
\text { (D) }\end{array}$ & $\begin{array}{r}\text { Error of closure } \\
\% \\
\text { (E) }\end{array}$ \\
\hline \multicolumn{6}{|l|}{ Males } \\
\hline Total & 447,412 & 488,827 & 527,260 & $-38,433$ & -7.29 \\
\hline NAl & 319,067 & 350,771 & 348,615 & 2,156 & 0.62 \\
\hline Métis & 107,138 & 114,830 & 154,559 & $-39,729$ & -25.70 \\
\hline Inuit & 21,207 & 23,226 & 24,086 & -860 & -3.57 \\
\hline Total without Métis & 340,273 & 373,997 & 372,701 & 1,296 & 0.35 \\
\hline \multicolumn{6}{|l|}{ Females } \\
\hline Total & 456,840 & 498,968 & 539,245 & $-40,277$ & -7.47 \\
\hline $\mathrm{NAl}$ & 328,927 & 360,865 & 364,459 & $-3,594$ & -0.99 \\
\hline Métis & 107,069 & 115,037 & 151,282 & $-36,245$ & -23.96 \\
\hline Inuit & 20,845 & 23,066 & 23,504 & -438 & -1.86 \\
\hline Total without Métis & 349,771 & 383,931 & 387,963 & $-4,032$ & -1.04 \\
\hline \multicolumn{6}{|l|}{ Both Sexes } \\
\hline Total & 904,252 & 987,795 & $1,066,505$ & $-78,710$ & -7.38 \\
\hline NAI & 647,993 & 711,636 & 713,074 & $-1,438$ & -0.20 \\
\hline Métis & 214,207 & 229,867 & 305,841 & $-75,974$ & -24.84 \\
\hline Inuit & 42,051 & 46,292 & 47,590 & $-1,298$ & -2.73 \\
\hline Total without Métis & 690,045 & 757,928 & 760,664 & $-2,736$ & -0.36 \\
\hline
\end{tabular}

Since the error of closure for the Métis population is still extremely high, the simulations with changing levels of expectation of life at birth would show more positive results/successes.

Under the current methodology, we are substituting the life expectancy of NonStatus Indians for the Métis. We could improve this method by taking the average of life expectancy of Non-Status Indians and the Canadian total population. This would give us a higher life expectancy for the Métis and the error of closure would be reduced. 
Table 6

Evaluation of 1996 based Projections of Aboriginal Population (with Ethnic Mobility Assumption) with the 2001 Adjusted Census Counts, Canada

\begin{tabular}{|c|c|c|c|c|c|}
\hline & $\begin{array}{r}1996 \text { Adj. Census } \\
\text { Population Counts } \\
\text { (A) }\end{array}$ & $\begin{array}{r}\text { Projected } 2001 \\
\text { Population } \\
\text { (B) }\end{array}$ & $\begin{array}{r}2001 \text { Adj. Census } \\
\text { Population Counts } \\
\text { (C) }\end{array}$ & $\begin{array}{c}\text { Difference } \\
D=B-C \\
\text { (D) }\end{array}$ & $\begin{array}{r}\text { Error of closure } \\
\% \\
\text { (E) }\end{array}$ \\
\hline \multicolumn{6}{|l|}{ Males } \\
\hline Total & 447,412 & 492,938 & 527,260 & $-34,322$ & -6.51 \\
\hline NAI & 319,067 & 353,101 & 348,615 & 4,486 & 1.29 \\
\hline Métis & 107,138 & 116,519 & 154,559 & $-38,040$ & -24.61 \\
\hline Inuit & 21,207 & 23,318 & 24,086 & -768 & -3.19 \\
\hline Total without Métis & 340,273 & 376,419 & 372,701 & 3,718 & 1.00 \\
\hline \multicolumn{6}{|l|}{ Females } \\
\hline Total & 456,840 & 502,861 & 539,245 & $-36,384$ & -6.75 \\
\hline NAl & 328,927 & 363,067 & 364,459 & $-1,392$ & -0.38 \\
\hline Métis & 107,069 & 116,635 & 151,282 & $-34,647$ & -22.90 \\
\hline Inuit & 20,845 & 23,159 & 23,504 & -345 & -1.47 \\
\hline Total without Métis & 349,771 & 386,226 & 387,963 & $-1,737$ & -0.45 \\
\hline \multicolumn{6}{|l|}{ Both Sexes } \\
\hline Total & 904,252 & 995,799 & $1,066,505$ & $-70,706$ & -6.63 \\
\hline NAl & 647,993 & 716,168 & 713,074 & 3,094 & 0.43 \\
\hline Métis & 214,207 & 233,154 & 305,841 & $-72,687$ & -23.77 \\
\hline Inuit & 42,051 & 46,477 & 47,590 & $-1,113$ & -2.34 \\
\hline Total without Métis & 690,045 & 762,645 & 760,664 & 1,981 & 0.26 \\
\hline
\end{tabular}

We have estimated two alternative sets of the life expectancy at birth for Métis for the years 1996 and 2001. The first alternative estimate of life expectancy by sex is based on the average of the life expectancy at birth for the non-status Indians and the Canadian population. The second set of them is based on the average of the life expectancy at birth for the Registered Indians and the Canadian population. These life expectancies at birth are given below. 
Evaluation of Population Projections for the Aboriginal Identity Groups in Canada: 1996-2001

Table 7

Alternate methods to estimate E0 for Métis, 1996 and 2001

\begin{tabular}{lcccc}
\hline \multirow{2}{*}{ Aboriginal Identity groups } & \multicolumn{2}{c}{1996} & \multicolumn{2}{c}{2001} \\
& Male & Female & Male & Female \\
\hline Total Aboriginal & 67.7 & 74.6 & 69.5 & 75.8 \\
North American Indians & 69.3 & 75.7 & 71.4 & 76.8 \\
$\quad$ Registered Indians & 68.1 & 74.3 & 70.4 & 75.4 \\
$\quad$ Non-Status & 70.5 & 77.0 & 72.4 & 78.2 \\
Métis (a) & 71.7 & 77.6 & 73.7 & 78.8 \\
Métis (b) & 73.0 & 79.0 & 74.7 & 80.2 \\
Inuit & 62.1 & 70.6 & 63.5 & 71.7 \\
Total Canada & 75.4 & 81.0 & 77.0 & 82.2 \\
\hline
\end{tabular}

Note: (a) Métis = Average of E0 for Registered Indians and Canadian Population

(b) Métis = Average of E0 for Non-Status Indians and Canadian Population For other Aboriginal groups methods, see Table 3.

In Tables 8 to 11 we have compared the error of closures between the 2001 projected population and the 2001 adjusted census counts for the three Aboriginal groups using the alternative estimates of life expectancy at birth for Métis. In general, there has been a slight reduction in the error of closure for Métis group due to the improvement in the life expectancy at birth. The results of the error of closure for Métis population are summarized below:

\begin{tabular}{llcc}
\hline & $\begin{array}{c}\text { E0= } \\
\text { N.S. }\end{array}$ & $\begin{array}{c}\text { E0 = Average of } \\
\text { Non-Status } \\
\text { Indians and } \\
\text { Canadian } \\
\text { Population }\end{array}$ & $\begin{array}{c}\text { E0 = Average of } \\
\text { Registered } \\
\text { Indians and } \\
\text { Canadian } \\
\text { Population }\end{array}$ \\
\hline $\begin{array}{l}\text { 2001 Métis pop without } \\
\text { ethnicity }\end{array}$ & -24.84 & -24.60 & -24.71 \\
$\begin{array}{l}\text { 2001 Métis pop with } \\
\text { ethnicity }\end{array}$ & -23.77 & -23.52 & -23.63 \\
\hline
\end{tabular}


Ravi B. P. Verma

Table 8

Evaluation of 1996 based Projections of Aboriginal Population

(without ethnicity)

with the 2001 Adjusted Census Counts, Canada

Métis = Average EO at birth for Non-Status Indians and Canadian

Population, scenario rv96n

\begin{tabular}{|c|c|c|c|c|c|}
\hline & $\begin{array}{r}1996 \text { Adj. Census } \\
\text { Population Counts } \\
\text { (A) }\end{array}$ & $\begin{array}{c}\text { Projected } 2001 \\
\text { Population } \\
\text { (B) }\end{array}$ & $\begin{array}{r}2001 \text { Adj. Census } \\
\text { Population Counts } \\
\text { (C) }\end{array}$ & $\begin{array}{c}\text { Difference } \\
D=B-C \\
\text { (D) }\end{array}$ & $\begin{array}{r}\text { Error of closure } \\
\% \\
\text { (E) }\end{array}$ \\
\hline \multicolumn{6}{|l|}{ Males } \\
\hline Total & 447,412 & 489,258 & 527,260 & $-38,002$ & -7.21 \\
\hline NAl & 319.067 & 350,771 & 348.615 & 2.156 & 0.62 \\
\hline Métis & 107,138 & 115,261 & 154.559 & $-39,298$ & -25.43 \\
\hline Inuit & 21,207 & 23,226 & 24,086 & -860 & -3.57 \\
\hline Total without Métis & 340,273 & 373,997 & 372,701 & 1,296 & 0.35 \\
\hline \multicolumn{6}{|l|}{ Females } \\
\hline Total & 456,840 & 499,263 & 539,245 & $-39,982$ & -7.41 \\
\hline NAl & 328,927 & 360,865 & 364,459 & $-3,594$ & -0.99 \\
\hline Métis & 107,069 & 115,332 & 151,282 & $-35,950$ & -23.76 \\
\hline Inuit & 20,845 & 23,066 & 23,504 & -438 & -1.86 \\
\hline Total without Métis & 349,771 & 383,931 & 387,963 & $-4,032$ & -1.04 \\
\hline \multicolumn{6}{|l|}{ Both Sexes } \\
\hline Total & 904,252 & 988,521 & $1,066,505$ & $-77,984$ & -7.31 \\
\hline NAl & 647,993 & 711,636 & 713,074 & $-1,438$ & -0.20 \\
\hline Métis & 214,207 & 230,593 & 305,841 & $-75,248$ & -24.60 \\
\hline Inuit & 42,051 & 46,292 & 47,590 & $-1,298$ & -2.73 \\
\hline Total without Métis & 690,045 & 757,928 & 760,664 & $-2,736$ & -0.36 \\
\hline
\end{tabular}


Evaluation of Population Projections for the Aboriginal Identity Groups in Canada: 1996-2001

Table 9

Evaluation of 1996 based Projections of Aboriginal Population

(without ethnicity)

with the 2001 Adjusted Census Counts, Canada

Métis = Average EO at birth for Registered Indians and Canadian Population, scenario $r v 96 r$

\begin{tabular}{|c|c|c|c|c|c|}
\hline & $\begin{array}{r}1996 \text { Adj. Census } \\
\text { Population Counts } \\
\text { (A) }\end{array}$ & $\begin{array}{c}\text { Projected } 2001 \\
\text { Population } \\
\text { (B) }\end{array}$ & $\begin{array}{r}2001 \text { Adj. Census } \\
\text { Population Counts } \\
\text { (C) }\end{array}$ & $\begin{array}{c}\text { Difference } \\
D=B-C \\
\text { (D) }\end{array}$ & $\begin{array}{r}\text { Error of closure } \\
\% \\
\text { (E) } \\
\end{array}$ \\
\hline \multicolumn{6}{|l|}{ Males } \\
\hline Total & 447,412 & 489,165 & 527,260 & $-38,095$ & -7.23 \\
\hline NAl & 319,067 & 350,771 & 348,615 & 2,156 & 0.62 \\
\hline Métis & 107,138 & 115,168 & 154,559 & $-39,391$ & -25.49 \\
\hline Inuit & 21,207 & 23,226 & 24,086 & -860 & -3.57 \\
\hline Total without Métis & 340,273 & 373,997 & 372,701 & 1,296 & 0.35 \\
\hline \multicolumn{6}{|l|}{ Females } \\
\hline Total & 456,840 & 499,044 & 539,245 & $-40,201$ & -7.46 \\
\hline NAl & 328,927 & 360,865 & 364,459 & $-3,594$ & -0.99 \\
\hline Métis & 107,069 & 115,113 & 151,282 & $-36,169$ & -23.91 \\
\hline Inuit & 20,845 & 23,066 & 23,504 & -438 & -1.86 \\
\hline Total without Métis & 349,771 & 383,931 & 387,963 & $-4,032$ & -1.04 \\
\hline \multicolumn{6}{|l|}{ Both Sexes } \\
\hline Total & 904,252 & 988,209 & $1,066,505$ & $-78,296$ & -7.34 \\
\hline NAl & 647,993 & 711,636 & 713,074 & $-1,438$ & -0.20 \\
\hline Métis & 214,207 & 230,281 & 305,841 & $-75,560$ & -24.71 \\
\hline Inuit & 42,051 & 46,292 & 47,590 & $-1,298$ & -2.73 \\
\hline Total without Métis & 690,045 & 757,928 & 760,664 & $-2,736$ & -0.36 \\
\hline
\end{tabular}


Ravi B. P. Verma

Table 10

Evaluation of 1996-based Projections of Aboriginal Population (with Ethnic Mobility Assumption) with the 2001 Adjusted Census Counts, Canada

Métis = Average EO at birth for Registered Indians and Canadian Population, scenario rv96re

\begin{tabular}{|c|c|c|c|c|c|}
\hline & $\begin{array}{r}1996 \text { Adj. Census } \\
\text { Population Counts } \\
\text { (A) }\end{array}$ & $\begin{array}{c}\text { Projected } 2001 \\
\text { Population } \\
\text { (B) }\end{array}$ & $\begin{array}{r}2001 \text { Adj. Census } \\
\text { Population Counts } \\
\text { (C) }\end{array}$ & $\begin{array}{l}\text { Difference } \\
\text { D=B-C } \\
\text { (D) }\end{array}$ & $\begin{array}{r}\text { Error of closure } \\
\qquad \% \\
\text { (E) }\end{array}$ \\
\hline \multicolumn{6}{|l|}{ Males } \\
\hline Total & 447,412 & 493,282 & 527,260 & $-33,978$ & -6.44 \\
\hline NAl & 319,067 & 353,101 & 348,615 & 4,486 & 1.29 \\
\hline Métis & 107,138 & 116,863 & 154,559 & $-37,696$ & -24.39 \\
\hline Inuit & 21,207 & 23,318 & 24,086 & -768 & -3.19 \\
\hline Total without Métis & 340,273 & 376,419 & 372,701 & 3,718 & 1.00 \\
\hline \multicolumn{6}{|l|}{ Females } \\
\hline Total & 456,840 & 502,937 & 539,245 & $-36,308$ & -6.73 \\
\hline NAI & 328,927 & 363,067 & 364,459 & $-1,392$ & -0.38 \\
\hline Métis & 107,069 & 116,711 & 151,282 & $-34,571$ & -22.85 \\
\hline Inuit & 20,845 & 23,159 & 23,504 & -345 & -1.47 \\
\hline Total without Métis & 349,771 & 386,226 & 387,963 & $-1,737$ & -0.45 \\
\hline \multicolumn{6}{|l|}{ Both Sexes } \\
\hline Total & 904,252 & 996,219 & $1,066,505$ & $-70,286$ & -6.59 \\
\hline NAI & 647,993 & 716,168 & 713,074 & 3,094 & 0.43 \\
\hline Métis & 214,207 & 233,574 & 305,841 & $-72,267$ & -23.63 \\
\hline Inuit & 42,051 & 46,477 & 47,590 & $-1,113$ & -2.34 \\
\hline Total without Métis & 690,045 & 762,645 & 760,664 & 1,981 & 0.26 \\
\hline
\end{tabular}


Evaluation of Population Projections for the Aboriginal Identity Groups in Canada: 1996-2001

Table 11

Evaluation of 1996-based Projections of Aboriginal Population (with Ethnic Mobility Assumption) with the 2001 Adjusted Census Counts, Canada

Métis = Average EO at birth for Non-Status Indians and Canadian Population, scenario rv96ne

\begin{tabular}{|c|c|c|c|c|c|}
\hline & $\begin{array}{r}1996 \text { Adj. Census } \\
\text { Population Counts } \\
\text { (A) }\end{array}$ & $\begin{array}{r}\text { Projected } 2001 \\
\text { Population } \\
\text { (B) }\end{array}$ & $\begin{array}{r}2001 \text { Adj. Census } \\
\text { Population Counts } \\
\text { (C) }\end{array}$ & $\begin{array}{c}\text { Difference } \\
D=B-C \\
\text { (D) }\end{array}$ & $\begin{array}{r}\text { Error of closure } \\
\% \\
\text { (E) }\end{array}$ \\
\hline \multicolumn{6}{|l|}{ Males } \\
\hline Total & 447,412 & 493,380 & 527,260 & $-33,880$ & -6.43 \\
\hline NAl & 319,067 & 353,101 & 348,615 & 4,486 & 1.29 \\
\hline Métis & 107,138 & 116,961 & 154,559 & $-37,598$ & -24.33 \\
\hline Inuit & 21,207 & 23,318 & 24,086 & -768 & -3.19 \\
\hline Total without Métis & 340,273 & 376,419 & 372,701 & 3,718 & 1.00 \\
\hline \multicolumn{6}{|l|}{ Females } \\
\hline Total & 456,840 & 503,168 & 539,245 & $-36,077$ & -6.69 \\
\hline NAl & 328,927 & 363,067 & 364,459 & $-1,392$ & -0.38 \\
\hline Métis & 107,069 & 116,942 & 151,282 & $-34,340$ & -22.70 \\
\hline Inuit & 20,845 & 23,159 & 23,504 & -345 & -1.47 \\
\hline Total without Métis & 349,771 & 386,226 & 387,963 & $-1,737$ & -0.45 \\
\hline \multicolumn{6}{|l|}{ Both Sexes } \\
\hline Total & 904,252 & 996,548 & $1,066,505$ & $-69,957$ & -6.56 \\
\hline NAl & 647,993 & 716,168 & 713,074 & 3,094 & 0.43 \\
\hline Métis & 214,207 & 233,903 & 305,841 & $-71,938$ & -23.52 \\
\hline Inuit & 42,051 & 46,477 & 47,590 & $-1,113$ & -2.34 \\
\hline Total without Métis & 690,045 & 762,645 & 760,664 & 1,981 & 0.26 \\
\hline
\end{tabular}

The error of closure between the 2001 projected population with ethnicity and the adjusted census counts for the Métis group was the lowest (-23.54\%) when we estimated their life expectancy at birth based on the average life expectancy at birth for the non-status Indians and the Canadian population. However, taking the average of the mortality status of the non-status Indians and the Canadian population contradicts the historical definition of Métis. They are currently defined as: "Métis means a person who self-identifies as Métis, is of an historic Métis nation ancestry, is distinct from other Aboriginal peoples and is accepted by the Métis nation. "Historic Métis nation" means the Aboriginal 
Ravi B. P. Verma

people then known as Métis or half -breeds who resided in an historic Métis nation homeland which is the area of land in west central North America used and occupied as the traditional territory of the Métis or half-breeds as they were then known; Métis nation means the Aboriginal people descended from the historic Métis nation, which is now comprised of all Métis nation citizens and is one of the "Aboriginal peoples" within S.3.5 of the Constitution Act of 1982. "Distinct from other Aboriginal peoples" means distinct for cultural and nationhood purposes. (2002, Métis National Council, www.metisnation.ca). Half-breed refers to an offspring of mixed Indian and white origin. So, it would be more consistent with the historical concept of the Métis people to estimate their life expectancy at birth as the average of the life expectancy at birth of the Registered Indians and the Canadian population. In this case, the error of closure between the 2001 projected population with ethnicity and the modified level of mortality and the adjusted census counts was calculated to be slightly higher at $-23.63 \%$.

Now, let us examine the error of closure between the projected population and the adjusted census counts by age groups and sex for Canada. Tables 12.0 to 12.3 show the evaluation of 1996- based projections of the Aboriginal population (with ethnic mobility assumption) by age groups and sex, with the 2001 adjusted census counts, Canada. In Table 12.0 it is seen that the projected 2001 population for the total Aboriginal group in all age groups except the last age group, 85 and over is lower than the 2001 adjusted census population. These large differences between the projected and adjusted census counts for the total Aboriginal population in all age groups except the last age group could be largely due to not incorporating the assumption of the number of intragenerational mobility in the projection model. In particular, the effect of the intra-generational mobility was seen for the projection of the Métis population. In the last age group, 85 and over, the 2001 projected Aboriginal female population was considerably higher than the adjusted 2001 Census counts for females. This could be due to over-estimating the survival ratio for the female population in the last age group, 85 and over.

The errors of closure between the projected population and the adjusted census counts for the total Aboriginal group are lower than -12 percent in all age groups under 84 years of age. This pattern is true for the total male and female Aboriginal population. As we have considered the assumption of intergenerational ethnic mobility in the projection model, it can be seen that the error of closure is very small (under 3 per cent) in the age group 0-4. It is surprising to note that the error of closure between the projected population and the adjusted 2001 census counts for the female Aboriginal population aged 85 and over is extremely higher over the male Aboriginal population aged 85 and over. This also suggests that we should check the survival ratio for the last age group for the female population, particularly for the North American Indians. 
Now, let us consider the errors of closure by age groups for each Aboriginal identity group. In Tables 12.1 to 12.3 the errors of closure between the projected population and the adjusted 2001 census counts are shown. The errors of closure by age groups for the North American Indians and Inuit are considerably lower than those for the Métis population. The pattern of the projected population being lower than the adjusted census counts in all age groups except the last age group 85 and over holds true for the Métis group only. For the two other identity groups, North American and Inuit, the differences between the projected population and the adjusted 2001 census counts are positive in some age groups, and negative in some age groups. The problem of over-estimating the survival ratio for the female population in the last age group 85 and over seems to be evident for the North American Indian female population, as the error of closure is very high in the last age group. For the Inuit, the errors of closures in the last two age groups, 80-84 and $85+$ are very high. These differences could be due to small numbers. However, it appears that we have underestimated the TFR for the Inuit group, as the projected population in the age group $0-4$ for them is considerably lower by $11 \%$ over the adjusted census counts. One could also assume that the 2001 census counts for the children in the age group 0-4 for the Inuit group are over adjusted due to the net census undercounts.

\section{Conclusions}

Based on the above analyses of comparison of the projected population by the Aboriginal identity groups with the adjusted 2001 Census counts for them, it appears that the issue regarding the higher error of closure between the 2001 projected population and the 2001 adjusted census counts for the Métis group still remains and the issue is complex and important for further research. It shows that the inclusion of the demographic components and intergenerational ethnic mobility in the projection model did not explain the total population change over the period 1996-2001. In particularly, the Métis population was grossly under-projected as compared to their adjusted counts in the 2001 Census of Canada. This difference could be due to the fact that the projection model did not incorporate the assumption of intra-generational ethnic mobility. This type of ethnic mobility may result from a change in an individuals' ethnic affiliation between two points in time (Guimond, 1999, p. 195). Such changes over time in individual ethnic affiliation are difficult to predict, and if at all, perhaps such phenomena lend themselves more to short term "what if" scenarios (Norris, Clatworthy and Guimond, 2001, p. 5). How to estimate the number for intergenerational mobility for a short-term is also complex? In Table 13 it is seen that over the period 1996-2001, the growth of the Métis population was 
Ravi B. P. Verma

Table 12

Evaluation of 1996-based Projections of Aboriginal Population (with Ethnic Mobility Assumption)

by Age and Sex, with the 2001 Adjusted Census Counts, Canada

\begin{tabular}{|c|c|c|c|c|c|}
\hline & $\begin{array}{r}1996 \text { Adj. Census } \\
\text { Population Counts } \\
\text { (A) }\end{array}$ & $\begin{array}{c}\text { Projected } 2001 \\
\text { Population } \\
\text { (B) }\end{array}$ & $\begin{array}{r}2001 \text { Adj. Census } \\
\text { Population Counts } \\
\text { (C) }\end{array}$ & $\begin{array}{r}\begin{array}{c}\text { Difference } \\
\text { D=B-C } \\
\text { (D) }\end{array} \\
\end{array}$ & $\begin{array}{c}\text { Error of closure } \\
\% \\
(E) \\
\end{array}$ \\
\hline \multicolumn{6}{|l|}{ Male } \\
\hline Total & 447,412 & 493,282 & 527,254 & $-33,972$ & -6.44 \\
\hline $0-4$ & 57,872 & 56,474 & 57,663 & $-1,189$ & -2.06 \\
\hline $5-9$ & 54,706 & 57,631 & 62,846 & $-5,215$ & -8.30 \\
\hline $10-14$ & 48,710 & 54,563 & 59,068 & $-4,505$ & -7.63 \\
\hline $15-19$ & 43,570 & 48,394 & 51,419 & $-3,025$ & -5.88 \\
\hline $20-24$ & 39,343 & 43,116 & 42,181 & 935 & 2.22 \\
\hline $25-29$ & 38,522 & 38,981 & 41,341 & $-2,360$ & -5.71 \\
\hline $30-34$ & 36,992 & 38,205 & 40,730 & $-2,525$ & -6.20 \\
\hline $35-39$ & 32,249 & 36,638 & 41,196 & $-4,558$ & -11.06 \\
\hline $40-44$ & 24,997 & 31,813 & 35,315 & $-3,502$ & -9.92 \\
\hline $45-49$ & 20,425 & 24,474 & 27,336 & $-2,862$ & -10.47 \\
\hline $50-54$ & 14,721 & 19,756 & 21,665 & $-1,909$ & -8.81 \\
\hline $55-59$ & 11,516 & 14,005 & 15,854 & $-1,849$ & -11.66 \\
\hline $60-64$ & 8,866 & 10,645 & 11,088 & -443 & -3.99 \\
\hline $65-69$ & 6,035 & 7,826 & 8,468 & -642 & -7.59 \\
\hline $70-74$ & 4,216 & 5,022 & 5,297 & -275 & -5.20 \\
\hline $75-79$ & 2,478 & 3,188 & 3,222 & -34 & -1.05 \\
\hline $80-84$ & 1,326 & 1,591 & 1,623 & -32 & -1.97 \\
\hline $85+$ & 869 & 960 & 941 & 19 & 2.00 \\
\hline \multicolumn{6}{|c|}{ Female } \\
\hline Total & 456,840 & 502,937 & 539,249 & $-36,312$ & -6.73 \\
\hline $0-4$ & 54,772 & 53,449 & 55,092 & $-1,643$ & -2.98 \\
\hline $5-9$ & 52,079 & 54,572 & 59,548 & $-4,976$ & -8.36 \\
\hline $10-14$ & 46,724 & 51,978 & 56,796 & $-4,818$ & -8.48 \\
\hline $15-19$ & 41,508 & 46,629 & 49,716 & $-3,087$ & -6.21 \\
\hline $20-24$ & 40,807 & 41,398 & 43,736 & $-2,338$ & -5.35 \\
\hline $25-29$ & 40,604 & 40,705 & 43,029 & $-2,324$ & -5.40 \\
\hline $30-34$ & 40,756 & 40,469 & 43,227 & $-2,758$ & -6.38 \\
\hline $35-39$ & 35,549 & 40,546 & 43,953 & $-3,407$ & -7.75 \\
\hline $40-44$ & 27,364 & 35,245 & 38,583 & $-3,338$ & -8.65 \\
\hline $45-49$ & 21,948 & 27,004 & 30,149 & $-3,145$ & -10.43 \\
\hline $50-54$ & 15,425 & 21,547 & 23,255 & $-1,708$ & -7.34 \\
\hline $55-59$ & 12,399 & 15,024 & 16,598 & $-1,574$ & -9.48 \\
\hline $60-64$ & 9,440 & 11,898 & 12,673 & -775 & -6.11 \\
\hline $65-69$ & 6,700 & 8,821 & 9,023 & -202 & -2.24 \\
\hline $70-74$ & 4,794 & 5,999 & 6,198 & -199 & -3.21 \\
\hline $75-79$ & 2,981 & 3,966 & 3,991 & -25 & -0.62 \\
\hline $80-84$ & 1,780 & 2,167 & 2,345 & -178 & -7.59 \\
\hline $85+$ & 1,211 & 1,520 & 1,339 & 181 & 13.51 \\
\hline \multicolumn{6}{|c|}{ Both Sexes } \\
\hline Total & 904,252 & 996,219 & $1,066,503$ & $-70,284$ & -6.59 \\
\hline $0-4$ & 112,644 & 109,923 & 112,754 & $-2,831$ & -2.51 \\
\hline $5-9$ & 106,785 & 112,203 & 122,394 & $-10,191$ & -8.33 \\
\hline $10-14$ & 95,435 & 106,541 & 115,864 & $-9,323$ & -8.05 \\
\hline $15-19$ & 85,078 & 95,023 & 101,135 & $-6,112$ & -6.04 \\
\hline $20-24$ & 80,150 & 84,514 & 85,917 & $-1,403$ & -1.63 \\
\hline $25-29$ & 79,126 & 79,686 & 84,370 & $-4,684$ & -5.55 \\
\hline $30-34$ & 77,748 & 78,674 & 83,957 & $-5,283$ & -6.29 \\
\hline $35-39$ & 67,798 & 77,184 & 85,149 & $-7,965$ & -9.35 \\
\hline $40-44$ & 52,361 & 67,058 & 73,898 & $-6,840$ & -9.26 \\
\hline $45-49$ & 42,373 & 51,478 & 57,486 & $-6,008$ & -10.45 \\
\hline $50-54$ & 30,145 & 41,303 & 44,920 & $-3,617$ & -8.05 \\
\hline $55-59$ & 23,915 & 29,029 & 32,451 & $-3,422$ & -10.55 \\
\hline $60-64$ & 18,306 & 22,543 & 23,761 & $-1,218$ & -5.12 \\
\hline $65-69$ & 12,735 & 16,647 & 17,492 & -845 & -4.83 \\
\hline $70-74$ & 9,010 & 11,021 & 11,495 & -474 & -4.13 \\
\hline $75-79$ & 5,459 & 7,154 & 7,212 & -58 & -0.81 \\
\hline $80-84$ & 3,105 & 3,758 & 3,968 & -210 & -5.29 \\
\hline $85+$ & 2,080 & 2,480 & 2,280 & 200 & 8.76 \\
\hline
\end{tabular}


Evaluation of Population Projections for the Aboriginal Identity Groups in Canada: 1996-2001

Table 12.1

Evaluation of 1996-based Projections of North American Indian Population

(with Ethnic Mobility Assumption)

by Age and Sex, with the 2001 Adjusted Census Counts, Canada

\begin{tabular}{|c|c|c|c|c|c|}
\hline & $\begin{array}{r}1996 \text { Adj. Census } \\
\text { Population Counts } \\
\text { (A) }\end{array}$ & $\begin{array}{r}\text { Projected } 2001 \\
\text { Population } \\
\text { (B) }\end{array}$ & $\begin{array}{l}2001 \text { Adj. Census } \\
\text { Population Counts } \\
\text { (C) }\end{array}$ & $\begin{array}{r}\text { Difference } \\
\text { D=B-C } \\
\text { (D) }\end{array}$ & $\begin{array}{r}\text { Error of closure } \\
\% \\
\text { (E) }\end{array}$ \\
\hline \multicolumn{6}{|c|}{ (2) } \\
\hline Total & 319,067 & 353,101 & 348,616 & 4,485 & 1.29 \\
\hline $0-4$ & 42,816 & 41,813 & 40,879 & 934 & 2.28 \\
\hline 5-9 & 40,584 & 42,663 & 44,256 & $-1,593$ & -3.60 \\
\hline $10-14$ & 35,189 & 40,485 & 39,928 & 557 & 1.39 \\
\hline $15-19$ & 30,788 & 34,930 & 33,908 & 1,022 & 3.02 \\
\hline $20-24$ & 27,939 & 30,422 & 27,218 & 3,204 & 11.77 \\
\hline $25-29$ & 27,493 & 27,654 & 27,271 & 383 & 1.40 \\
\hline $30-34$ & 26,151 & 27,254 & 27,068 & 186 & 0.69 \\
\hline 35-39 & 22,672 & 25,882 & 26,522 & -640 & -2.41 \\
\hline $40-44$ & 16,987 & 22,342 & 22,237 & 105 & 0.47 \\
\hline $45-49$ & 13,656 & 16,604 & 16,965 & -361 & -2.13 \\
\hline 50-54 & 10,187 & 13,167 & 13,086 & 81 & 0.62 \\
\hline 55-59 & 7,761 & 9,657 & 9,840 & -183 & -1.86 \\
\hline $60-64$ & 6,095 & 7,147 & 6,787 & 360 & 5.30 \\
\hline 65-69 & 4,241 & 5,370 & 5,179 & 191 & 3.70 \\
\hline 70-74 & 3,047 & 3,533 & 3,533 & 0 & 0.01 \\
\hline 75-79 & 1,797 & 2,314 & 2,175 & 139 & 6.40 \\
\hline $80-84$ & 953 & 1,154 & 1,094 & 60 & 5.45 \\
\hline $85+$ & 711 & 710 & 671 & 39 & 5.79 \\
\hline \multicolumn{6}{|c|}{ Female } \\
\hline Total & 328,927 & 363,067 & 364,474 & $-1,407$ & -0.39 \\
\hline $0-4$ & 40,194 & 39,505 & 39,334 & 171 & 0.44 \\
\hline $5-9$ & 38,094 & 40,049 & 41,958 & $-1,909$ & -4.55 \\
\hline $10-14$ & 34,406 & 38,020 & 38,974 & -954 & -2.45 \\
\hline $15-19$ & 29,603 & 34,335 & 32,888 & 1,447 & 4.40 \\
\hline $20-24$ & 29,007 & 29,517 & 28,781 & 736 & 2.56 \\
\hline $25-29$ & 29,057 & 28,925 & 28,696 & 229 & 0.80 \\
\hline 30-34 & 29,283 & 28,958 & 29,195 & -237 & -0.81 \\
\hline 35-39 & 25,286 & 29,137 & 29,390 & -253 & -0.86 \\
\hline $40-44$ & 19,241 & 25,079 & 25,147 & -68 & -0.27 \\
\hline $45-49$ & 15,400 & 19,009 & 19,760 & -751 & -3.80 \\
\hline 50-54 & 10,892 & 15,136 & 15,145 & -9 & -0.06 \\
\hline 55-59 & 9,031 & 10,617 & 10,997 & -380 & -3.46 \\
\hline $60-64$ & 6,815 & 8,667 & 8,672 & -5 & -0.06 \\
\hline 65-69 & 4,789 & 6,355 & 6,033 & 322 & 5.34 \\
\hline 70-74 & 3,469 & 4,263 & 4,214 & 49 & 1.16 \\
\hline 75-79 & 2,148 & 2,845 & 2,768 & 77 & 2.78 \\
\hline $80-84$ & 1,334 & 1,542 & 1,613 & -71 & -4.40 \\
\hline $85+$ & 879 & 1,108 & 909 & 199 & 21.88 \\
\hline \multicolumn{6}{|c|}{ Both Sexes } \\
\hline Total & 647,993 & 716,168 & 713,091 & 3,077 & 0.43 \\
\hline $0-4$ & 83,010 & 81,318 & 80,213 & 1,105 & 1.38 \\
\hline $5-9$ & 78,678 & 82,712 & 86,214 & $-3,502$ & -4.06 \\
\hline $10-14$ & 69,595 & 78,505 & 78,902 & -397 & -0.50 \\
\hline $15-19$ & 60,391 & 69,265 & 66,796 & 2,469 & 3.70 \\
\hline $20-24$ & 56,946 & 59,939 & 55,999 & 3,940 & 7.04 \\
\hline $25-29$ & 56,550 & 56,579 & 55,967 & 612 & 1.09 \\
\hline $30-34$ & 55,434 & 56,212 & 56,263 & -51 & -0.09 \\
\hline $35-39$ & 47,958 & 55,019 & 55,912 & -893 & -1.60 \\
\hline $40-44$ & 36,228 & 47,421 & 47,384 & 37 & 0.08 \\
\hline $45-49$ & 29,055 & 35,613 & 36,725 & $-1,112$ & -3.03 \\
\hline $50-54$ & 21,079 & 28,303 & 28,231 & 72 & 0.26 \\
\hline $55-59$ & 16,792 & 20,274 & 20,838 & -564 & -2.71 \\
\hline $60-64$ & 12,910 & 15,814 & 15,459 & 355 & 2.29 \\
\hline $65-69$ & 9,030 & 11,725 & 11,212 & 513 & 4.58 \\
\hline $70-74$ & 6,516 & 7,796 & 7,747 & 49 & 0.63 \\
\hline $75-79$ & 3,945 & 5,159 & 4,943 & 216 & 4.37 \\
\hline $80-84$ & 2,287 & 2,696 & 2,707 & -11 & -0.42 \\
\hline $85+$ & 1,590 & 1,818 & 1,580 & 238 & 15.05 \\
\hline
\end{tabular}


Ravi B. P. Verma

Table 12.2

Evaluation of 1996-based Projections of Métis Population (with Ethnic Mobility Assumption)

by Age and Sex, with the 2001 Adjusted Census Counts, Canada

Métis = Average E0 at birth for Registered Indians and Canadian Population, scenario rv96re

\begin{tabular}{|c|c|c|c|c|c|}
\hline & $\begin{array}{l}1996 \text { Adj. Census } \\
\text { Population Counts } \\
\text { (A) }\end{array}$ & $\begin{array}{r}\text { Projected } 2001 \\
\text { Population } \\
\text { (B) }\end{array}$ & $\begin{array}{r}2001 \text { Adj. Census } \\
\text { Population Counts } \\
\text { (C) }\end{array}$ & $\begin{array}{c}\text { Difference } \\
\text { D=B-C } \\
\text { (D) }\end{array}$ & $\begin{array}{c}\text { Error of closure } \\
\% \\
\text { (E) }\end{array}$ \\
\hline \multicolumn{6}{|c|}{$(0)$} \\
\hline Total & 107,138 & 116,863 & 154,557 & $-37,694$ & -24.39 \\
\hline $0-4$ & 11,911 & 11,967 & 13,662 & $-1,695$ & -12.41 \\
\hline $5-9$ & 11,146 & 11,888 & 15,470 & $-3,582$ & -23.15 \\
\hline $10-14$ & 11,057 & 11,136 & 16,063 & $-4,927$ & -30.67 \\
\hline $15-19$ & 10,563 & 11,025 & 14,976 & $-3,951$ & -26.38 \\
\hline $20-24$ & 9,475 & 10,502 & 12,919 & $-2,417$ & -18.71 \\
\hline $25-29$ & 9,069 & 9,424 & 12,221 & $-2,797$ & -22.89 \\
\hline $30-34$ & 9,189 & 9,016 & 11,728 & $-2,712$ & -23.13 \\
\hline $35-39$ & 8,332 & 9,129 & 12,993 & $-3,864$ & -29.74 \\
\hline $40-44$ & 7,068 & 8,251 & 11,817 & $-3,566$ & -30.18 \\
\hline $45-49$ & 5,954 & 6,954 & 9,466 & $-2,512$ & -26.54 \\
\hline $50-54$ & 4,046 & 5,809 & 7,749 & $-1,940$ & -25.03 \\
\hline $55-59$ & 3,312 & 3,887 & 5,482 & $-1,595$ & -29.09 \\
\hline $60-64$ & 2,367 & 3,089 & 3,914 & -825 & -21.07 \\
\hline $65-69$ & 1,550 & 2,102 & 2,917 & -815 & -27.95 \\
\hline $70-74$ & 1,031 & 1,293 & 1,567 & -274 & -17.46 \\
\hline $75-79$ & 586 & 776 & 962 & -186 & -19.33 \\
\hline $80-84$ & 353 & 382 & 421 & -39 & -9.19 \\
\hline $85+$ & 131 & 233 & 230 & 3 & 1.30 \\
\hline \multicolumn{6}{|c|}{ Female } \\
\hline Total & 107,069 & 116,711 & 151,273 & $-34,562$ & -22.85 \\
\hline $0-4$ & 11,492 & 11,285 & 12,896 & $-1,611$ & -12.49 \\
\hline $5-9$ & 10,981 & 11,458 & 14,479 & $-3,021$ & -20.86 \\
\hline $10-14$ & 9,999 & 10,958 & 14,837 & $-3,879$ & -26.14 \\
\hline $15-19$ & 9,932 & 9,975 & 14,551 & $-4,576$ & -31.45 \\
\hline $20-24$ & 9,848 & 9,907 & 13,056 & $-3,149$ & -24.12 \\
\hline $25-29$ & 9,600 & 9,827 & 12,294 & $-2,467$ & -20.07 \\
\hline $30-34$ & 9,720 & 9,576 & 12,089 & $-2,513$ & -20.79 \\
\hline $35-39$ & 9,009 & 9,680 & 12,754 & $-3,074$ & -24.11 \\
\hline $40-44$ & 7,287 & 8,936 & 12,127 & $-3,191$ & -26.32 \\
\hline $45-49$ & 5,754 & 7,183 & 9,508 & $-2,325$ & -24.45 \\
\hline $50-54$ & 3,990 & 5,641 & 7,292 & $-1,651$ & -22.64 \\
\hline $55-59$ & 2,878 & 3,889 & 5,133 & $-1,244$ & -24.24 \\
\hline $60-64$ & 2,236 & 2,770 & 3,580 & -810 & -22.63 \\
\hline $65-69$ & 1,687 & 2,112 & 2,705 & -593 & -21.93 \\
\hline $70-74$ & 1,192 & 1,539 & 1,803 & -264 & -14.64 \\
\hline $75-79$ & 761 & 1,020 & 1,122 & -102 & -9.11 \\
\hline $80-84$ & 401 & 578 & 662 & -84 & -12.69 \\
\hline $85+$ & 302 & 377 & 385 & -8 & -2.08 \\
\hline \multicolumn{6}{|c|}{ Both Sexes } \\
\hline Total & 214,207 & 233,574 & 305,830 & $-72,256$ & -23.63 \\
\hline $0-4$ & 23,403 & 23,252 & 26,558 & $-3,306$ & -12.45 \\
\hline $5-9$ & 22,127 & 23,346 & 29,948 & $-6,602$ & -22.05 \\
\hline $10-14$ & 21,056 & 22,094 & 30,900 & $-8,806$ & -28.50 \\
\hline $15-19$ & 20,494 & 21,000 & 29,527 & $-8,527$ & -28.88 \\
\hline $20-24$ & 19,323 & 20,409 & 25,975 & $-5,566$ & -21.43 \\
\hline $25-29$ & 18,669 & 19,251 & 24,515 & $-5,264$ & -21.47 \\
\hline $30-34$ & 18,909 & 18,592 & 23,818 & $-5,226$ & -21.94 \\
\hline $35-39$ & 17,341 & 18,809 & 25,748 & $-6,939$ & -26.95 \\
\hline $40-44$ & 14,355 & 17,187 & 23,944 & $-6,757$ & -28.22 \\
\hline $45-49$ & 11,709 & 14,137 & 18,974 & $-4,837$ & -25.49 \\
\hline $50-54$ & 8,036 & 11,450 & 15,040 & $-3,590$ & -23.87 \\
\hline $55-59$ & 6,190 & 7,776 & 10,615 & $-2,839$ & -26.75 \\
\hline $60-64$ & 4,603 & 5,859 & 7,494 & $-1,635$ & -21.82 \\
\hline $65-69$ & 3,237 & 4,214 & 5,623 & $-1,409$ & -25.05 \\
\hline $70-74$ & 2,223 & 2,832 & 3,370 & -538 & -15.95 \\
\hline $75-79$ & 1,347 & 1,796 & 2,084 & -288 & -13.83 \\
\hline $80-84$ & 754 & 960 & 1,083 & -123 & -11.33 \\
\hline $85+$ & 433 & 610 & 615 & -5 & -0.81 \\
\hline
\end{tabular}


Evaluation of Population Projections for the Aboriginal Identity Groups in Canada: 1996-2001

Table 12.3

Evaluation of 1996-based Projections of Inuit Population (with Ethnic Mobility Assumption)

by Age and Sex, with the 2001 Adjusted Census Counts, Canada

\begin{tabular}{|c|c|c|c|c|c|}
\hline & $\begin{array}{r}1996 \text { Adj. Census } \\
\text { Population Counts } \\
\text { (A) }\end{array}$ & $\begin{array}{c}\text { Projected } 2001 \\
\text { Population } \\
\text { (B) }\end{array}$ & $\begin{array}{r}2001 \text { Adj. Census } \\
\text { Population Counts } \\
\text { (C) }\end{array}$ & $\begin{array}{r}\begin{array}{c}\text { Difference } \\
\text { D }=\mathrm{B}-\mathrm{C} \\
\text { (D) }\end{array} \\
\end{array}$ & $\begin{array}{r}\text { Error of closure } \\
\% \\
\text { (E) }\end{array}$ \\
\hline \multicolumn{6}{|c|}{$x_{1-1}$} \\
\hline Total & 21,207 & 23,318 & 24,081 & -763 & -3.17 \\
\hline $0-4$ & 3,145 & 2,694 & 3,122 & -428 & -13.70 \\
\hline $5-9$ & 2,976 & 3,080 & 3,121 & -41 & -1.31 \\
\hline $10-14$ & 2,465 & 2,942 & 3,077 & -135 & -4.39 \\
\hline $15-19$ & 2,219 & 2,439 & 2,535 & -96 & -3.80 \\
\hline $20-24$ & 1,929 & 2,192 & 2,043 & 149 & 7.28 \\
\hline $25-29$ & 1,960 & 1,903 & 1,849 & 54 & 2.92 \\
\hline $30-34$ & 1,652 & 1,935 & 1,934 & 1 & 0.06 \\
\hline $35-39$ & 1,245 & 1,627 & 1,681 & -54 & -3.18 \\
\hline $40-44$ & 943 & 1,220 & 1,262 & -42 & -3.30 \\
\hline $45-49$ & 815 & 916 & 906 & 10 & 1.12 \\
\hline $50-54$ & 488 & 780 & 831 & -51 & -6.10 \\
\hline $55-59$ & 443 & 461 & 532 & -71 & -13.27 \\
\hline $60-64$ & 404 & 409 & 387 & 22 & 5.71 \\
\hline $65-69$ & 244 & 354 & 372 & -18 & -4.94 \\
\hline $70-74$ & 138 & 196 & 198 & -2 & -1.01 \\
\hline $75-79$ & 95 & 98 & 85 & 13 & 15.29 \\
\hline $80-84$ & 20 & 55 & 108 & -53 & -49.07 \\
\hline $85+$ & 27 & 17 & 40 & -23 & -57.50 \\
\hline \multicolumn{6}{|c|}{ Female } \\
\hline Total & 20,845 & 23,159 & 23,501 & -342 & -1.46 \\
\hline $0-4$ & 3,086 & 2,659 & 2,862 & -203 & -7.10 \\
\hline $5-9$ & 3,004 & 3,065 & 3,111 & -46 & -1.47 \\
\hline $10-14$ & 2,319 & 3,000 & 2,985 & 15 & 0.49 \\
\hline $15-19$ & 1,974 & 2,319 & 2,277 & 42 & 1.86 \\
\hline $20-24$ & 1,953 & 1,974 & 1,899 & 75 & 3.94 \\
\hline $25-29$ & 1,947 & 1,953 & 2,039 & -86 & -4.21 \\
\hline $30-34$ & 1,753 & 1,935 & 1,943 & -8 & -0.41 \\
\hline $35-39$ & 1,254 & 1,729 & 1,809 & -80 & -4.42 \\
\hline $40-44$ & 835 & 1,230 & 1,308 & -78 & -5.97 \\
\hline $45-49$ & 794 & 812 & 882 & -70 & -7.89 \\
\hline $50-54$ & 543 & 770 & 818 & -48 & -5.89 \\
\hline $55-59$ & 489 & 518 & 467 & 51 & 10.92 \\
\hline $60-64$ & 390 & 461 & 420 & 41 & 9.66 \\
\hline $65-69$ & 224 & 354 & 285 & 69 & 24.21 \\
\hline $70-74$ & 132 & 197 & 181 & 16 & 8.90 \\
\hline $75-79$ & 72 & 101 & 100 & 1 & 0.73 \\
\hline $80-84$ & 45 & 47 & 70 & -23 & -32.86 \\
\hline $85+$ & 31 & 35 & 45 & -10 & -22.22 \\
\hline \multicolumn{6}{|c|}{ Both Sexes } \\
\hline Total & 42,051 & 46,477 & 47,583 & $-1,106$ & -2.32 \\
\hline $0-4$ & 6,231 & 5,353 & 5,984 & -631 & -10.54 \\
\hline $5-9$ & 5,980 & 6,145 & 6,232 & -87 & -1.39 \\
\hline $10-14$ & 4,784 & 5,942 & 6,063 & -121 & -1.99 \\
\hline $15-19$ & 4,193 & 4,758 & 4,812 & -54 & -1.12 \\
\hline $20-24$ & 3,881 & 4,166 & 3,942 & 224 & 5.67 \\
\hline $25-29$ & 3,907 & 3,856 & 3,888 & -32 & -0.82 \\
\hline $30-34$ & 3,405 & 3,870 & 3,877 & -7 & -0.17 \\
\hline $35-39$ & 2,499 & 3,356 & 3,489 & -133 & -3.82 \\
\hline $40-44$ & 1,778 & 2,450 & 2,570 & -120 & -4.66 \\
\hline $45-49$ & 1,609 & 1,728 & 1,787 & -59 & -3.32 \\
\hline $50-54$ & 1,030 & 1,550 & 1,649 & -99 & -5.99 \\
\hline $55-59$ & 933 & 979 & 999 & -20 & -1.96 \\
\hline $60-64$ & 793 & 870 & 807 & 63 & 7.76 \\
\hline $65-69$ & 467 & 708 & 657 & 51 & 7.70 \\
\hline $70-74$ & 270 & 393 & 379 & 14 & 3.72 \\
\hline $75-79$ & 167 & 199 & 185 & 14 & 7.41 \\
\hline $\begin{array}{l}80-84 \\
85+\end{array}$ & $\begin{array}{l}65 \\
58\end{array}$ & $\begin{array}{r}102 \\
52\end{array}$ & $\begin{array}{r}178 \\
85\end{array}$ & $\begin{array}{l}-76 \\
-33\end{array}$ & $\begin{array}{l}-42.70 \\
-38.82\end{array}$ \\
\hline
\end{tabular}


Ravi B. P. Verma

considerably high, increasing from 214,000 to 306,000. About 92,000 Métis were added over the five years. The growth of the Métis population was also noticed in all age groups except three older cohorts, 70-74, 75-79 and 80+. At the Canada level, the assumption of internal migration was zero, and the assumption of the international migration was assumed to be negligible for the growth of Aboriginal identity groups, hence they cannot be accountable for the growth of the Métis population. The role of increasing life expectancy at birth for explaining the growth of the Métis population over the period 1996-2001 was also found to be insignificant. So, such high growth of the Métis population over the period 1996-2001 could be due to a non-demographic factor, intragenerational ethnic mobility. Before suggesting some thoughts for considering a number for intra-generational mobility, it is worth reviewing some situational and administrative changes which have happened in Canada which might have had some influences on the non-Aboriginal people as well as the Aboriginal identity groups for changing their identities as Métis.

There are numerous factors/events which may raise an individual's consciousness of his/her heritage. Some of these factors are listed below:

- the way in which the question about identity is asked by the Census, as well as through shifts in the individual's attachment to or affiliation with a group;

- 1982-2005 Constitutional changes and crises.

Based on the review of legislative changes related to the Aboriginal people, and increasing awareness among them for their rights, program and services, it appears that the ethnic intra-generational mobility, particularly for Métis, will continue to rise or same in Canada. However, it is difficult to measure precisely for the estimation /projection of Métis population.

\section{Thoughts for the Indirect Estimation of the Intra-generational Ethnic Mobility}

For estimation purposes, should we take the number of the error of closure between the 2001 projected population and the adjusted census counts as the crude number of inter-generational mobility? In considering this approach, however, we could assign a minimum level of the error of closure for the Métis population. In order to estimate the minimum level of the error of closure for the Métis, I propose to take the minimum value of the error of closure for the Métis by computing the average of the error of closure between the 2001 projected 
Evaluation of Population Projections for the Aboriginal Identity Groups in Canada: 1996-2001

Table 13

Changes in the Métis Adjusted Census Population by Cohort

of Age Group and Sex between 1996 and 2001, Canada

\begin{tabular}{|c|c|c|c|}
\hline & $\begin{array}{l}1996 \text { Adj. Census } \\
\text { Population Counts } \\
\text { (B) }\end{array}$ & $\begin{array}{l}2001 \text { Adj. Census } \\
\text { Population Counts } \\
\text { (C) }\end{array}$ & $\begin{array}{l}\text { Difference by cohort } \\
\text { (D=C-B) } \\
\text { (2001 vs } 1996 \text { Census) } \\
\text { (D) }\end{array}$ \\
\hline \multicolumn{4}{|r|}{ 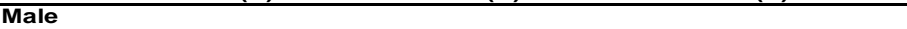 } \\
\hline Total & 107,138 & 154,557 & 47,418 \\
\hline $0-4$ & 11,911 & 13,662 & 13,662 \\
\hline $5-9$ & 11,146 & 15,470 & 3,559 \\
\hline $10-14$ & 11,057 & 16,063 & 4,917 \\
\hline $15-19$ & 10,563 & 14,976 & 3,920 \\
\hline $20-24$ & 9,475 & 12,919 & 2,357 \\
\hline $25-29$ & 9,069 & 12,221 & 2,745 \\
\hline 30-34 & 9,189 & 11,728 & 2,660 \\
\hline $35-39$ & 8,332 & 12,993 & 3,805 \\
\hline $40-44$ & 7,068 & 11,817 & 3,485 \\
\hline $45-49$ & 5,954 & 9,466 & 2,398 \\
\hline $50-54$ & 4,046 & 7,749 & 1,794 \\
\hline $55-59$ & 3,312 & 5,482 & 1,436 \\
\hline $60-64$ & 2,367 & 3,914 & 602 \\
\hline $65-69$ & 1,550 & 2,917 & 551 \\
\hline $70-74$ & 1,031 & 1,567 & 17 \\
\hline $75-79$ & 586 & 962 & -69 \\
\hline $80-84$ & 353 & 421 & -165 \\
\hline $85+$ & 131 & 230 & -254 \\
\hline \multicolumn{4}{|c|}{ Female } \\
\hline Total & 107,069 & 151,273 & 44,205 \\
\hline $0-4$ & 11,492 & 12,896 & 12,896 \\
\hline $5-9$ & 10,981 & 14,479 & 2,986 \\
\hline $10-14$ & 9,999 & 14,837 & 3,856 \\
\hline $15-19$ & 9,932 & 14,551 & 4,552 \\
\hline $20-24$ & 9,848 & 13,056 & 3,124 \\
\hline $25-29$ & 9,600 & 12,294 & 2,447 \\
\hline $30-34$ & 9,720 & 12,089 & 2,489 \\
\hline 35-39 & 9,009 & 12,754 & 3,034 \\
\hline $40-44$ & 7,287 & 12,127 & 3,118 \\
\hline $45-49$ & 5,754 & 9,508 & 2,220 \\
\hline $50-54$ & 3,990 & 7,292 & 1,538 \\
\hline $55-59$ & 2,878 & 5,133 & 1,143 \\
\hline $60-64$ & 2,236 & 3,580 & 702 \\
\hline $65-69$ & 1,687 & 2,705 & 469 \\
\hline $70-74$ & 1,192 & 1,803 & 116 \\
\hline $75-79$ & 761 & 1,122 & -70 \\
\hline $80-84$ & 401 & 662 & -99 \\
\hline $85+$ & 302 & 385 & -317 \\
\hline \multicolumn{4}{|c|}{ Both Sexes } \\
\hline Total & 214,207 & 305,830 & 91,623 \\
\hline $0-4$ & 23,403 & 26,558 & 26,558 \\
\hline 5-9 & 22,127 & 29,948 & 6,545 \\
\hline $10-14$ & 21,056 & 30,900 & 8,773 \\
\hline $15-19$ & 20,494 & 29,527 & 8,472 \\
\hline $20-24$ & 19,323 & 25,975 & 5,481 \\
\hline $25-29$ & 18,669 & 24,515 & 5,192 \\
\hline $30-34$ & 18,909 & 23,818 & 5,149 \\
\hline $35-39$ & 17,341 & 25,748 & 6,839 \\
\hline $40-44$ & 14,355 & 23,944 & 6,603 \\
\hline $45-49$ & 11,709 & 18,974 & 4,619 \\
\hline $50-54$ & 8,036 & 15,040 & 3,332 \\
\hline $55-59$ & 6,190 & 10,615 & 2,579 \\
\hline $60-64$ & 4,603 & 7,494 & 1,304 \\
\hline $65-69$ & 3,237 & 5,623 & 1,020 \\
\hline $70-74$ & 2,223 & 3,370 & 132 \\
\hline $75-79$ & 1,347 & 2,084 & -139 \\
\hline $80-84$ & 754 & 1,083 & -264 \\
\hline $85+$ & 433 & 615 & -571 \\
\hline
\end{tabular}


population and the adjusted census counts for the North American Indians and Inuit, since they constitute $75 \%$ of the total Aboriginal population in Canada. Then, let us deduct the minimum level of the error of closure from the original error of closure for the Métis, and the residual error of closure could be the assumed level of intra-general ethnic mobility for Métis population over the five year period, 1996-2001. This approach could be argued in light of the stability of the phenomenon.

\section{Acknowledgements:}

The author appreciates the feedback received from Margaret Michalowski and other team members such as Marie-France Germain and Shirley Loh, Development and Demographic Methods Section, Demography Division, Statistics Canada in developing these projections. I also thank Julie Dussault for providing technical assistance and Ian Kisbee for editorial assistance.

\section{References:}

Canadian Encyclopaedia. http://www.collectionscanada.ca/primeministers/h44022-e.html.

Employment Equity Act, 1995. http://laws.justice.gc.ca/en/E-5.401/48801.html.

Finès, P. 2004. Does the Income-Mortality Gradient Vary across Urban Areas in Canada? Paper presented at the annual meetings of the Canadian Population Society. University of Manitoba, Winnipeg.

Guimond, E. 1999. Ethnic Mobility and the Demographic Growth of Canada's Aboriginal Population from 1986 to 1996, published in Report on the demographic situation in Canada 1998-1999, current demographic analysis, Catalogue no. 91-209-XPE. Ottawa, Statistics Canada. pp. 187-200.

Indian Affairs and Northern Development. 2001. Indian Act, 1985. Ottawa.

Inuit: www.itk.ca.

Létourneau, E. 1994. Projections de la population des Inuit du Québec, 1991 2016. Statistiques sociodémographiques, Bureau de la statistique du Québec. 
Evaluation of Projections of Populations for the Aboriginal Identity Groups in Canada, 1996-2001

Métis National Council. 2002. www.metisnation.ca

Minister of Indian Affairs and Northern Development, 2002. Services for First Nations People: A Government of Canada Guide. www.aincinac.gc.ca.

Norris, M.J., S. Clatworthy and E. Guimond. 2001. Demography, Legislation and Ethnic Mobility: Considerations and Implications for Projections of Canada's Aboriginal Populations. Paper presented at 2001 annual meeting of the Population Association of America, Washington, D.C.

Nunatsiavut Land Claims deal signed, January 2005, Labrador. London Free Press, January 23, 2005-12-22

Ram, B. 2003. Emerging Patterns of Aboriginal Fertility, 1966-1971 to 19962001. Paper presented at the annual meeting of the Canadian Population Society. Halifax. June, also published in Canadian Studies in Population, vol. 31, No. 2, 2004.

Teillet, J. 2004. Métis Law Summary 2004. Chapter 2. Pape \& Salter, barristers $\&$ solicitors, Toronto. 
Ravi B. P. Verma

Appendix Table 1

Total Fertility Rate and Mean Age of Fertility, Canada, 1921-2000

\begin{tabular}{ccccccccc} 
Year & TFR & Mean Age & Year & TFR & Mean Age & Year & TFR & Mean Age \\
\hline 1921 & 3.47 & 29.50 & 1948 & 3.43 & 28.67 & 1975 & 1.83 & 26.71 \\
1922 & 3.40 & 29.62 & 1949 & 3.44 & 28.61 & 1976 & 1.78 & 26.74 \\
1923 & 3.25 & 29.77 & 1950 & 3.44 & 28.56 & 1977 & 1.75 & 26.77 \\
1924 & 3.25 & 29.81 & 1951 & 3.49 & 28.46 & 1978 & 1.70 & 26.83 \\
1925 & 3.14 & 29.70 & 1952 & 3.61 & 28.35 & 1979 & 1.70 & 26.93 \\
1926 & 3.36 & 30.13 & 1953 & 3.69 & 28.30 & 1980 & 1.68 & 26.96 \\
1927 & 3.32 & 30.11 & 1954 & 3.81 & 28.26 & 1981 & 1.65 & 27.07 \\
1928 & 3.29 & 30.05 & 1955 & 3.81 & 28.22 & 1982 & 1.63 & 27.11 \\
1929 & 3.22 & 29.90 & 1956 & 3.84 & 28.11 & 1983 & 1.62 & 27.22 \\
1930 & 3.28 & 29.88 & 1957 & 3.91 & 28.01 & 1984 & 1.62 & 27.35 \\
1931 & 3.20 & 29.86 & 1958 & 3.87 & 27.94 & 1985 & 1.61 & 27.45 \\
1932 & 3.09 & 29.96 & 1959 & 3.93 & 27.87 & 1986 & 1.59 & 27.54 \\
1933 & 2.86 & 29.99 & 1960 & 3.91 & 27.81 & 1987 & 1.57 & 27.64 \\
1934 & 2.80 & 30.09 & 1961 & 3.86 & 27.78 & 1988 & 1.60 & 27.71 \\
1935 & 2.75 & 30.00 & 1962 & 3.78 & 27.75 & 1989 & 1.65 & 27.73 \\
1936 & 2.69 & 29.96 & 1963 & 3.69 & 27.75 & 1990 & 1.71 & 27.79 \\
1937 & 2.64 & 29.84 & 1964 & 3.52 & 27.80 & 1991 & 1.71 & 27.81 \\
1938 & 2.70 & 29.68 & 1965 & 3.16 & 27.76 & 1992 & 1.71 & 27.92 \\
1939 & 2.65 & 29.61 & 1966 & 2.82 & 27.62 & 1993 & 1.68 & 28.01 \\
1940 & 2.76 & 29.36 & 1967 & 2.60 & 27.43 & 1994 & 1.68 & 28.08 \\
1941 & 2.83 & 29.16 & 1968 & 2.46 & 27.30 & 1995 & 1.67 & 28.17 \\
1942 & 2.96 & 29.13 & 1969 & 2.41 & 27.26 & 1996 & 1.62 & 28.35 \\
1943 & 3.08 & 29.17 & 1970 & 2.34 & 27.15 & 1997 & 1.56 & 28.50 \\
1944 & 3.00 & 29.31 & 1971 & 2.13 & 27.07 & 1998 & 1.54 & 28.55 \\
1945 & 3.01 & 29.33 & 1972 & 1.96 & 26.96 & 1999 & 1.53 & 28.69 \\
1946 & 3.36 & 29.02 & 1973 & 1.88 & 26.82 & 2000 & 1.49 & 28.83 \\
1947 & 3.58 & 28.72 & 1974 & 1.83 & 26.79 & & &
\end{tabular}


Evaluation of Population Projections for the Aboriginal Identity Groups in Canada: 1996-2001

\section{Appendix Graph 1 \\ Total Fertility Rate and Mean Age of Fertility, Canada, 1921-2000}

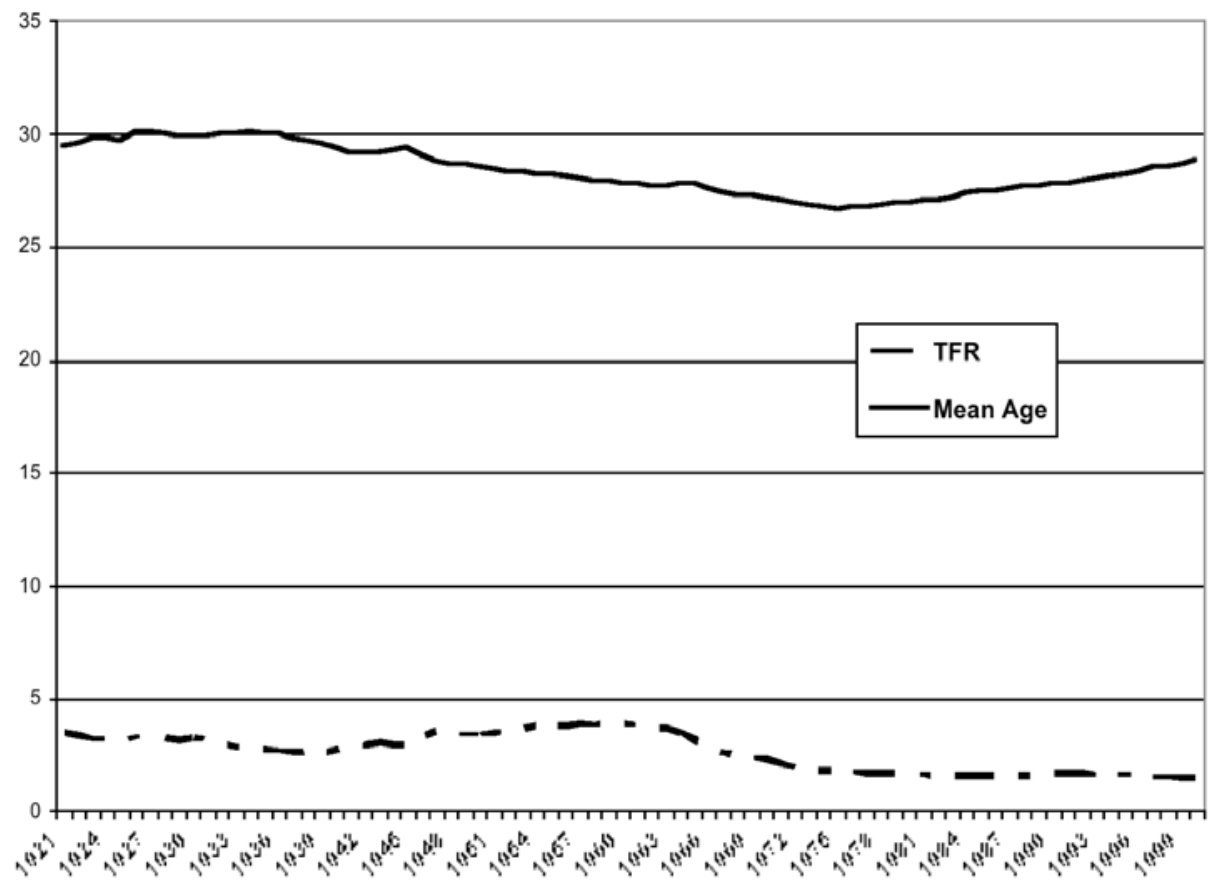

